\title{
Systematic Review \\ Mobile Learning Applications for Refugees: A Systematic Literature Review
}

\author{
Maria Drolia ${ }^{1}$ (D), Stamatios Papadakis ${ }^{1}$ (D), Eirini Sifaki ${ }^{2}$ (D) and Michail Kalogiannakis ${ }^{1, *(D)}$ \\ 1 Department of Preschool Education, Faculty of Education, University of Crete, 74100 Crete, Greece; \\ maria.e.drolia@gmail.com (M.D.); stpapadakis@uoc.gr (S.P.) \\ 2 School of Humanities and Social Sciences, Department of Language \& Intercultural Studies, \\ University of Thessaly, 38221 Volos, Greece; eirini_sifaki@yahoo.gr \\ * Correspondence: mkalogian@uoc.gr; Tel.: +30-2831077889
}

Citation: Drolia, M.; Papadakis, S.; Sifaki, E.; Kalogiannakis, M. Mobile Learning Applications for Refugees: A Systematic Literature Review. Educ Sci. 2022, 12, 96. https://doi.org/ 10.3390/educsci12020096

Academic Editor: James Albright

Received: 30 November 2021

Accepted: 24 January 2022

Published: 30 January 2022

Publisher's Note: MDPI stays neutral with regard to jurisdictional claims in published maps and institutional affiliations.

Copyright: (c) 2022 by the authors. Licensee MDPI, Basel, Switzerland. This article is an open access article distributed under the terms and conditions of the Creative Commons Attribution (CC BY) license (https:// creativecommons.org/licenses/by/ $4.0 /)$.

\begin{abstract}
The proliferation of mobile devices in everyday life since the end of the 20th century has led to mobile applications for educational purposes and the creation of the research field of mobile learning. Despite the extended research interest on the effectiveness of this field, there is limited research on mobile learning for various social groups, such as refugees, students with learning difficulties and disabilities. Due to the unprecedented number (over one hundred million) of refugees during the second decade of the 21st century worldwide, many NGOs (Non-Governmental Organizations) and UN (United Nations) initiatives have proposed leveraging mobile learning for refugee educational needs. This research article focuses on mobile learning for refugee education. Namely, the present systematic literature review results from 2015 to 2020 will give a concrete picture of the recently existing mobile learning apps for refugees and their characteristics. According to the research findings, 15 characteristics were collected out of 14 applications. According to prior literature, areas of agreement or discrepancies in the field were found. Two new -to previous literaturecharacteristics were revealed: interwoven psychological and educational features and refugees' cultural features in the apps. The summarization and categorization of the app's characteristics aim to contribute to mobile learning research and impact game developers, educators, and NGOs according to refugee needs. The limitations of this study and issues for further exploration will also be discussed in the last sections.
\end{abstract}

Keywords: refugees; mobile devices; mobile learning; app characteristics; app design; mobile applications; multicultural education; distance learning

\section{Introduction}

The large numbers of forcibly displaced humans since 2013 have resulted in a "global refugee crisis," as was mentioned in the literature [1-3]. According to UNHCR [4], over eighty million refugees from Syria, Iraq, Afghanistan, Asia, and Eastern Africa sought shelter worldwide. Among them, approximately 33 million refugees were under 18 [4]. Refugees usually spend an average of 17-20 years away from their countries [5,6]. Thus, the risk of a "lost generation" emerges if refugee children and youths are not provided with quality educational opportunities [2,7-9].

Against a backdrop of increasingly protracted refugee situations worldwide, refugee education is essential for poverty reduction, economic growth, and promotion of health and wellbeing [10-13]. Unfortunately, current school enrollment rates revealed the gap in access to education for refugees. Namely, only $63 \%$ of refugee children worldwide had access to primary education, $24 \%$ to secondary education, and $3 \%$ graduated from higher education [14]. Considering that refugee students formed a heterogeneous group regarding living conditions, learning or emotional needs, and socio-cultural background, refugee education seemed to be particularly complex $[15,16])$. Refugees face poor living conditions, physical and mental health issues, language barriers, and learning difficulties. They also 
face challenges with their education accreditation (lost documents) and coping with the host country's educational system due to the absence of a coherent curriculum and high academic and socio-cultural requirements. The above has been mentioned as some of the most prevailing challenges in refugees' education [17-20].

Most refugees own at least one mobile device [21-23]. It is considered vital for survival and used during refugees' escape trips and upon arrival in their host country [24,25]. Thus, leveraging mobile devices (i.e., mobile learning) has been proposed to enhance refugee education [26,27]. However, there is limited research on mobile learning for refugees [8,21,28]. Thus, a systematic literature review was conducted to gather the characteristics of recent mobile learning apps for refugees.

\section{Mobile Learning and Refugees}

Generally, the research field of mobile learning has been examined by the end of the 20 th century and especially since 2008, with multiple research projects focusing on defining the area [29-36] and on the effect of mobile learning's application [37-41]. Some of the mobile learning advantages are the increased students' motivation and engagement. These are due to the multimedia use and the atopic and asynchronous nature of provided learning (no space and time restrictions), resulting in higher learning performances [20,31,42-48]. Mobile learning has shown to be crucial in situations in which access to education is prohibited (e.g., virus pandemic, natural disasters, war conflicts, far-to-reach areas). The Covid-19 pandemic has led to the explosive growth of mobile learning apps downloaded. Significantly, users downloaded 936 million educational mobile apps (Android and Apple) during the first three months of 2020 [49]. On the other hand, the disadvantages of mobile learning mainly focused on the difficulty in navigating through the app, cognitive overload, and social marginalization [45,50-53].

Researchers mentioned mobile learning to contribute to refugee education $[5,14,54,55]$ by providing access $[11,18,56]$ and improving education quality $[2,8,9,57]$. Due to the beneficial capabilities of mobile learning, refugees could access personalized and engaging educational programs. They were also able to receive the appropriate scaffolding and make progress at their own pace, with no need for books and stationery $[28,58,59]$. On the other hand, some of the difficulties which refugees still seemed to encounter in mobile learning were: essential or consistent availability of electricity and Internet access, gender inequity in accessing mobile devices, online safety, challenges in navigating through the app, cognitive overload, social marginalization and lack of relevance of app's content to refugees' everyday lives $[31,57,60,61]$. The characteristics of the apps which were proposed more frequently were: free of charge, offline, multilingual applications with engaging multimedia design, provided feedback/scaffolding, social interactions within the app, and content related to refugee lives [62-65].

\section{Systematic Literature Review (SLR)}

\subsection{Scope of Review}

There seem to be a variety of mobile learning applications which focus on different student groups depending on age and/or educational purpose. Hence, it aimed to investigate the recent mobile applications created for the student group of refugees. Although NGOs and UN agencies have invested in mobile learning opportunities, mobile learning apps for refugees seem complicated to find $[8,26]$. Moreover, research on the characteristics of mobile learning for refugees has not been covered yet. The purpose of the current systematic literature review is to gather and critically analyze recent mobile learning apps designed for refugees during the period 2015-2020 to answer the following research questions:

1. Which are the recent mobile learning apps that have been used for refugees' education?

2. What are the characteristics of recent mobile learning apps for refugees? 


\subsection{Review Process}

The researchers developed a review protocol to enhance the systematic search's consistency and reliability based on the review questions. The present study set specific eligibility criteria to select and include the studies relevant to our research topic (see Table 1). There were no limitations regarding the geographical area of research, the age of the target group, the educational stage (i.e., early childhood, primary, secondary or higher education), or the content/subject of education (e.g., Language, Mathematics, Science, etc.)

Table 1. Eligibility criteria of Systematic Literature Review.

\begin{tabular}{|c|c|c|}
\hline \multicolumn{3}{|c|}{ Eligibility CRITERIA } \\
\hline \# & Inclusion Criteria & Exclusion Criteria \\
\hline 1 & $\begin{array}{l}\text { The aim of mobile apps should be the } \\
\text { education of refugees. }\end{array}$ & $\begin{array}{l}\text { The aim of the mobile app was not } \\
\text { educational or targeted to } \\
\text { refugee populations. }\end{array}$ \\
\hline 2 & $\begin{array}{l}\text { The mobile learning apps should be targeted } \\
\text { at the refugee population. }\end{array}$ & $\begin{array}{l}\text { The study does not include an app' } \\
\text { description but information about the } \\
\text { education of refugees and } \\
\text { mobile learning. }\end{array}$ \\
\hline 3 & $\begin{array}{l}\text { The study should include at least two } \\
\text { characteristics of the described mobile apps. }\end{array}$ & $\begin{array}{l}\text { The study does not mention the app } \\
\text { characteristics that were used. }\end{array}$ \\
\hline 4 & $\begin{array}{l}\text { The study should be published online, in the } \\
\text { English language, and be accessible from the } \\
\text { researchers. }\end{array}$ & The study is not written in English. \\
\hline 5 & The study should be a peer-reviewed paper. & The study is listed in another database. \\
\hline 6 & $\begin{array}{l}\text { The publication period of the study should } \\
\text { be from 2015-to } 2020 \text {. }\end{array}$ & $\begin{array}{l}\text { The study is only published as } \\
\text { an abstract. }\end{array}$ \\
\hline
\end{tabular}

An extensive literature search in seven databases and a search engine for scholarly literature and academic resources (i.e., Google Scholar) was conducted for the current SLR. The databases were selected by the SLR objectives and the scientific research field. The chosen databases were BASE, Eric, JSTOR, Learning Tech Lib, SAGE, Scopus, and Taylor and Francis. Google Scholar was also selected to cover the "grey literature," i.e., documents relevant to our search content but not included in the databases.

Additionally, four core concepts aligned with our research were identified (Mobile learning, Education, Mobile app, and Refugees). Alternative keywords for these key terms were found and put together in three search strings using simple (parentheses and quotation marks) and "Boolean" operators (AND, OR) (see Tables 2 and 3). Researchers conducted a mini-scale SLR from 2018-2020, during February and March 2021, to check the review protocol and be aware of any emerging issues. Afterward, a more extensive search (from 2015-2020) was conducted during June and July 2021 (Tables 3 and A1 in Appendix A).

Table 2. Keyword synonyms.

\begin{tabular}{cc} 
Mobile Learning & $\begin{array}{c}\text { Online Learning, Electronic Learning, Distant Learning, } \\
\text { Ubiquitous Learning, } \\
\text { Game-Based Learning }\end{array}$ \\
\hline $\begin{array}{c}\text { Education } \\
\text { Mobile app } \\
\text { Refugees }\end{array}$ & $\begin{array}{c}\text { Educational, instructional, teaching, learning, training } \\
\text { app, game, edutainment, smartphone app, tablet app } \\
\text { forcibly removed people, after war crisis, emergent situations }\end{array}$ \\
\hline
\end{tabular}


Table 3. The number of research data found in the literature review search during 2015-2020.

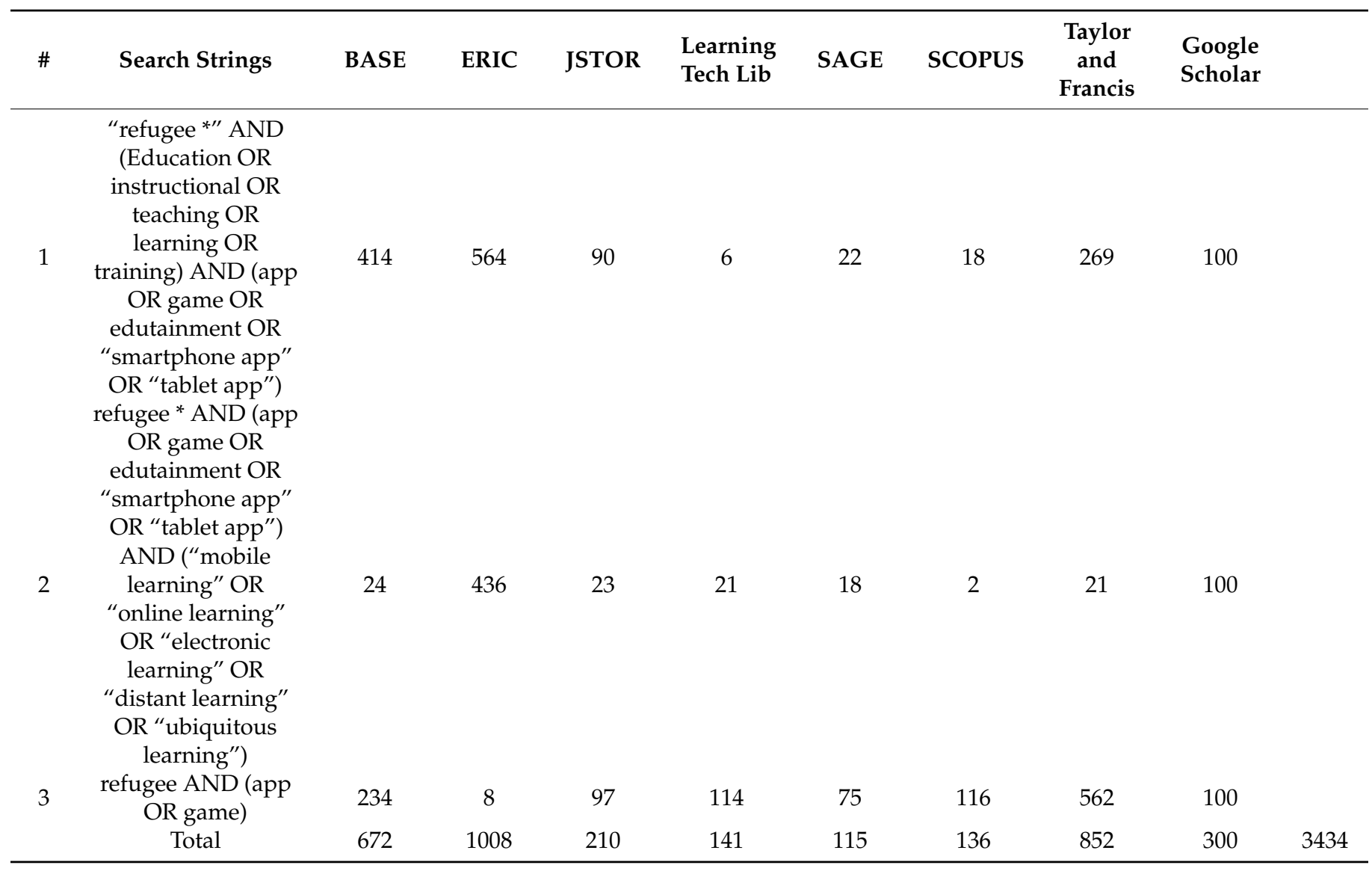

According to the inclusion criteria, the researchers used filters in each database (such as publication date, language, peer-reviewed papers, education subject) to limit the number of irrelevant findings. Moreover, the specific syntax and restrictions of each database were considered. In the case of character or Boolean operator limitation in one database (JSTOR), researchers adjusted the two first search strings accordingly. In the case of Google Scholar, the three hundred most relevant results were selected, in line with Haddaway et al.'s [66] argument. The references of the final chosen articles were used as a snowball method to trace other relevant articles. Lastly, the researchers searched the selected apps in the two major app platforms (Google Play and App store) to retrieve supplementary information.

According to the Preferred Reporting Items for Systematic Reviews and Meta-Analyses (PRISMA) framework, the researchers constructed two flow diagrams to depict all the actions taken during the current systematic literature review (see Figures 1 and A1 in the Appendix A). After the final selection of the eligible apps, a meta-analysis was conducted based on prior literature frameworks on evaluating educational apps for the general public (e.g., four pillars model $[67,68]$ ) or mainly for refugee populations (e.g., Serious Game Assessment Framework) [69,70]. 


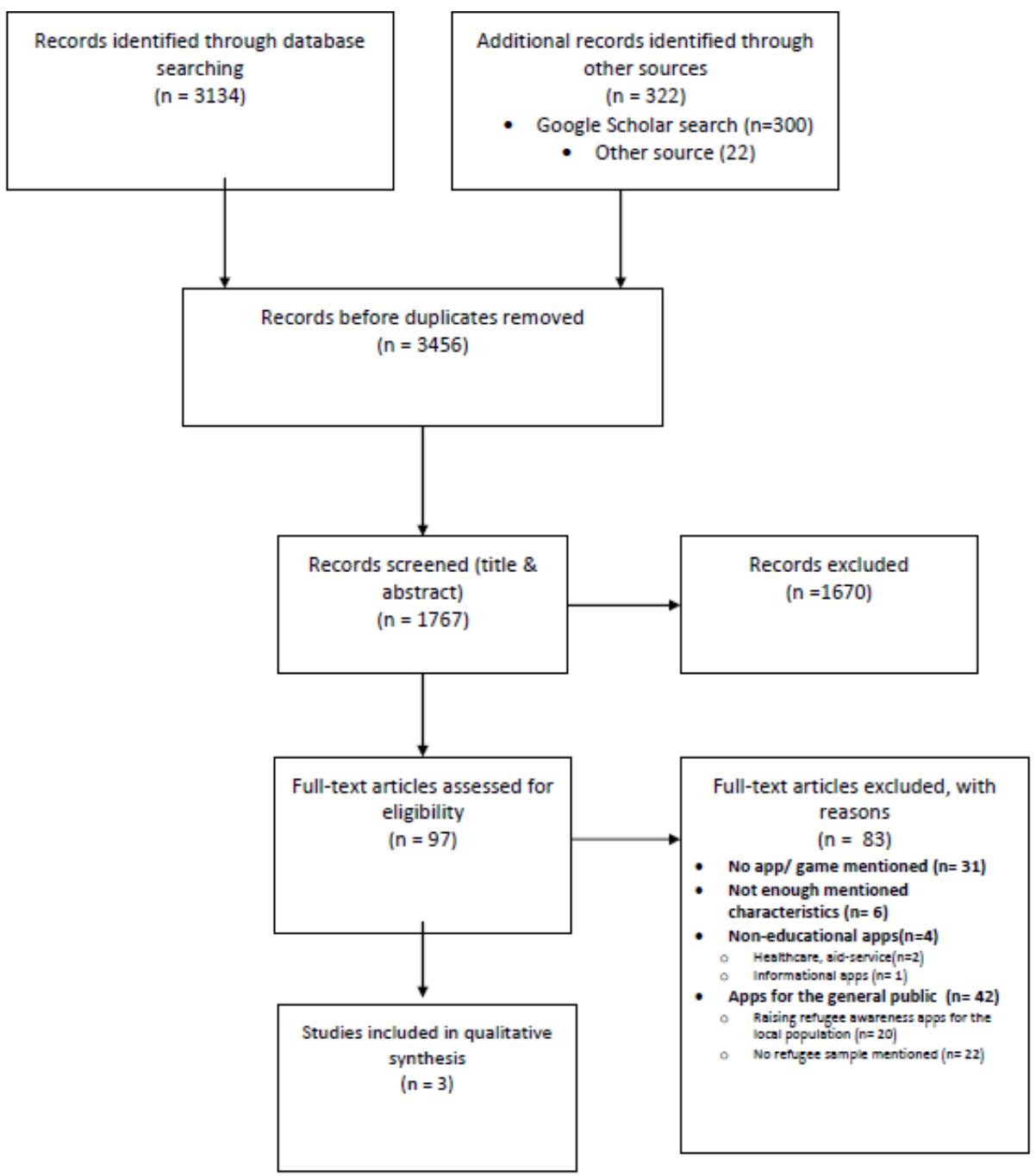

Figure 1. Flow diagram of SLR 2015-2020 according to PRISMA.

\section{Findings}

During the search for research articles on mobile learning apps for refugees, the authors came to an exact conclusion in line with the view of Weibert et al. [28] and Taftaf and Williams [8]. Notably, from the 3456 sources found in the electronic databases and search engines during 2015-2020, only 14 apps were found to meet the inclusion criteria (see Table 4). The selected articles were read thoroughly, and the mentioned characteristics of the apps were extracted, as shown in Tables 5 and 6. Examples of the mobile apps' objectives, which were excluded, were: healthcare information or tracking apps, aid-service or informational apps, apps about collecting important info from refugees, already existing for the general public apps and games/apps for raising awareness about refugees in the local population.

Table 4. Mobile learning apps for refugee education during 2015-2020.

\begin{tabular}{ccccc}
\hline Name of the App & $\begin{array}{c}\text { Age/Level of } \\
\text { Education }\end{array}$ & Content Area & App Objective & Author (s)-Year \\
\hline 1. Dinner Talk & Primary education & $\begin{array}{c}\text { Host country's } \\
\text { Language } \\
\text { Learning }\end{array}$ & $\begin{array}{c}\text { Language learning (thus far } \\
\text { available in English, } \\
\text { German, French and } \\
\text { Swedish) }\end{array}$ & $\begin{array}{c}\text { Jantke, Arnold and } \\
\text { Bosecker, (2016) [71]; } \\
\text { Schuldt, Sachse and } \\
\text { Buckens, (2017) [72] }\end{array}$ \\
\hline
\end{tabular}


Table 4. Cont.

\begin{tabular}{|c|c|c|c|c|c|}
\hline & Name of the App & $\begin{array}{l}\text { Age/Level of } \\
\text { Education }\end{array}$ & Content Area & App Objective & Author (s)-Year \\
\hline 2. & $\begin{array}{l}\text { Cannot Wait to } \\
\text { Learn-ELS }\end{array}$ & Primary Education & $\begin{array}{l}\text { Mathematics, } \\
\text { Reading skills and } \\
\text { Wellbeing }\end{array}$ & $\begin{array}{l}\text { Mathematics and Arabic } \\
\text { reading skills acquisition by } \\
\text { out-of-school students } \\
\text { based on the Sudanese } \\
\text { national curriculum }\end{array}$ & $\begin{array}{l}\text { Stubbé et al. (2016) [73]; } \\
\text { Koval-Saifi and Plass } \\
\text { (2018 a) [74]; } \\
\text { Brown et al., (2020) [75] }\end{array}$ \\
\hline 3. & Ankommen & Adult refugees & $\begin{array}{l}\text { Host country's } \\
\text { language learn- } \\
\text { ing/Integration }\end{array}$ & $\begin{array}{l}\text { Informational app for } \\
\text { refugees arriving in } \\
\text { Germany. German language } \\
\text { learning }\end{array}$ & $\begin{array}{l}\text { Benton and Glennie (2016) } \\
\text { [76] }\end{array}$ \\
\hline 4. & $\begin{array}{l}\text { Feed the monster } \\
\text {-Winning app in } \\
\text { Edu4Syria app } \\
\text { contest }\end{array}$ & $\begin{array}{l}\text { Early and Primary } \\
\text { education }\end{array}$ & $\begin{array}{l}\text { Native language } \\
\text { learning }\end{array}$ & $\begin{array}{c}\text { Basic language learning for } \\
\text { Syrian refugee children in } \\
\text { the Arabic } \\
\text { language-psychological } \\
\text { wellbeing. }\end{array}$ & $\begin{array}{l}\text { Koval-Saifi and Plass } \\
\qquad(2018 a)[74] ; \\
\text { Comings, }(2020)[77]\end{array}$ \\
\hline 5. & $\begin{array}{l}\text { Antura and the } \\
\text { Letters-Winning } \\
\text { app in Edu4Syria } \\
\text { app contest }\end{array}$ & $\begin{array}{l}\text { Early and Primary } \\
\text { education }\end{array}$ & $\begin{array}{l}\text { Native language } \\
\text { learning }\end{array}$ & $\begin{array}{l}\text { Basic language learning for } \\
\text { Syrian refugee children in } \\
\text { the Arabic language }\end{array}$ & $\begin{array}{l}\text { Koval-Saifi and Plass } \\
\qquad(2018 b)[78]\end{array}$ \\
\hline 6. & Qysas & $\begin{array}{c}\text { Early Primary } \\
\text { education (Grades } \\
1-3)\end{array}$ & $\begin{array}{l}\text { Reading skills in } \\
\text { mother language }\end{array}$ & $\begin{array}{l}\text { Foundational Arabic } \\
\text { reading skills, reading } \\
\text { comprehension skills, and } \\
\text { access to a library of } 125 \\
\text { interactive books }\end{array}$ & $\begin{array}{l}\text { Koval-Saifi and Plass } \\
\text { (2018a) [74] }\end{array}$ \\
\hline 7. & RefInfo & Adult refugees & $\begin{array}{l}\text { Informational and } \\
\text { Host country's } \\
\text { language learning }\end{array}$ & $\begin{array}{l}\text { Informational app for } \\
\text { refugees arriving in Holland. } \\
\text { Dutch language learning }\end{array}$ & $\begin{array}{l}\text { Baldi and Ribeiro, (2018) } \\
\text { [79] }\end{array}$ \\
\hline 8. & Hopscotch & $\begin{array}{l}\text { Early and Primary } \\
\text { education }\end{array}$ & $\begin{array}{l}\text { Host country's } \\
\text { language learning } \\
\text { psychological } \\
\text { wellbeing }\end{array}$ & $\begin{array}{l}\text { Combining gaming, } \\
\text { exercise, and German } \\
\text { language learning for young } \\
\text { refugee children }\end{array}$ & $\begin{array}{c}\text { Breitbart et al., (2018) } \\
\text { mentioned in Taftaf and } \\
\text { Williams [8]. }\end{array}$ \\
\hline 9. & Project Hope & $\begin{array}{c}\text { Primary and } \\
\text { Secondary } \\
\text { education (9-14 } \\
\text { years old refugee } \\
\text { students) }\end{array}$ & $\begin{array}{l}\text { Host country's } \\
\text { language learning } \\
\text { (Turkish), } \\
\text { Psychological } \\
\text { wellbeing, and } \\
\text { 21st-century skills } \\
\text { acquisition }\end{array}$ & $\begin{array}{l}\text { Although the program was } \\
\text { based on four existing apps } \\
\text { and games, new versions } \\
\text { targeted at refugee students } \\
\text { were created. }\end{array}$ & Sirin et al. (2018) [80] \\
\hline 10. & Minclusion & Adult refugees & $\begin{array}{l}\text { Host country's } \\
\text { language learning }\end{array}$ & $\begin{array}{l}\text { Swedish language learning } \\
\text { from Arabic immigrants and } \\
\text { refugees to learn and } \\
\text { practice every day authentic } \\
\text { dialogues with a mix of } \\
\text { audio and video recordings }\end{array}$ & $\begin{array}{c}\text { Al-Sabbagh et al. (2019) } \\
\text { [64] }\end{array}$ \\
\hline 11. & EngStarter & Higher Education & Engineering & $\begin{array}{l}\text { Real-world solutions to } \\
\text { refugee students' problems } \\
\text { while learning fundamental } \\
\text { concepts of engineering, } \\
\text { electronic circuits, } \\
\text { programming, and the } \\
\text { Internet of Things (IoT) }\end{array}$ & $\begin{array}{l}\text { de Freitas and DeBoer, } \\
\text { (2019) [63] }\end{array}$ \\
\hline
\end{tabular}


Table 4. Cont.

\begin{tabular}{|c|c|c|c|c|c|}
\hline & Name of the App & $\begin{array}{l}\text { Age/Level of } \\
\text { Education }\end{array}$ & Content Area & App Objective & Author (s)-Year \\
\hline 12. & Worldreader & $\begin{array}{l}\text { Early and Primary } \\
\text { education }\end{array}$ & $\begin{array}{l}\text { Literacy } \\
\text { acquisition }\end{array}$ & $\begin{array}{l}\text { Leveraging Mobile Phones } \\
\text { for Reading to Young } \\
\text { Children in developing } \\
\text { countries (e.g., India and } \\
\text { Jordan) }\end{array}$ & $\begin{array}{l}\text { Smith and Crane, (2019) } \\
\text { [81] }\end{array}$ \\
\hline 13. & StudiareMigrando & $\begin{array}{l}\text { Secondary } \\
\text { education }\end{array}$ & $\begin{array}{l}\text { Host country's } \\
\text { language learning } \\
\text { and Preparation } \\
\text { for the state exam. }\end{array}$ & $\begin{array}{l}\text { Two modules regarding } \\
\text { Italian Language learning } \\
\text { andfive modules regarding } \\
\text { knowledge and skills } \\
\text { development for the final } \\
\text { Italian state examination of } \\
\text { the first cycle of education }\end{array}$ & Fulantelli et al. (2019) [82] \\
\hline 14. & Workeen & Adult refugees & Vocational training & $\begin{array}{c}\text { Job seeking and soft } \\
\text { workplace skills training }\end{array}$ & ANSA (2020) [62] \\
\hline
\end{tabular}

Table 5. Educational Content characteristics of the found mobile learning apps for refugees during 2015-2020.

\begin{tabular}{|c|c|c|c|c|c|c|c|}
\hline App & $\begin{array}{c}\text { User } \\
\text { Appropriate } \\
\text { Content }\end{array}$ & $\begin{array}{c}\text { Learning } \\
\text { Approach/Theory }\end{array}$ & $\begin{array}{l}\text { Scaffolding } \\
\text { on Learning } \\
\text { Content }\end{array}$ & $\begin{array}{c}\text { Explanation } \\
\text { of Terms }\end{array}$ & $\begin{array}{l}\text { Visualization } \\
\text { of Progress }\end{array}$ & $\begin{array}{l}\text { Social In- } \\
\text { teractions }\end{array}$ & $\begin{array}{c}\text { Addressing } \\
\text { Psychological } \\
\text { Needs of } \\
\text { Refugees }\end{array}$ \\
\hline 1 & NS * & $\begin{array}{c}\text { Exploratory } \\
\text { Game-based } \\
\text { learning and } \\
\text { Collaborative } \\
\text { learning }\end{array}$ & NS & NS & + & + & - \\
\hline & & Game-based & & & & & \\
\hline 2 & + & $\begin{array}{l}\text { Design approach } \\
\text { of mastery of } \\
\text { learning } 1\end{array}$ & + & + & + & - & NS \\
\hline 3 & + & NS & NS & + & - & NS & NS \\
\hline 4 & + & $\begin{array}{c}\text { Game-based } \\
\text { learning }\end{array}$ & + & - & + & - & + \\
\hline 5 & + & $\begin{array}{l}\text { Game-based } \\
\text { learning }\end{array}$ & + & + & + & - & - \\
\hline 6 & + & NS & + & - & - & - & - \\
\hline 7 & + & NS & NS & NS & NS & NS & - \\
\hline 8 & NS & $\begin{array}{l}\text { Game-based } \\
\text { learning }\end{array}$ & + & NS & - & - & + \\
\hline 9 & NS & NS & + & - & + & - & + \\
\hline 10 & + & NS & NS & NS & - & + & - \\
\hline 11 & + & $\begin{array}{l}\text { Real-world } \\
\text { problem-solving } \\
\text { approach }\end{array}$ & + & - & - & - & - \\
\hline 12 & + & NS & + & - & + & - & - \\
\hline 13 & + & NS & + & NS & + & $\begin{array}{l}\text { + only an } \\
\text { e-learning } \\
\text { platform }\end{array}$ & NS \\
\hline 14 & + & NS & + & - & NS & - & - \\
\hline
\end{tabular}

${ }^{1}$ Mini-games use the pedagogy of mastery learning. Children must attain a given level of competency on one topic before continuing to more complex concepts [75]. * Technical and Design Characteristics: + = positive, -=negative, NS = not specified. 
Table 6. Technical and design characteristics of the found mobile learning apps for refugees during 2015-2020.

\begin{tabular}{|c|c|c|c|c|c|c|c|c|}
\hline $\begin{array}{l}\text { App } \\
\text { No. }\end{array}$ & $\begin{array}{l}\text { Free of } \\
\text { Charge }\end{array}$ & $\begin{array}{l}\text { No Internet } \\
\text { Dependable }\end{array}$ & Language & $\begin{array}{l}\text { Refugees' } \\
\text { Cultural } \\
\text { Features }\end{array}$ & $\begin{array}{c}\text { Scaffolding } \\
\text { in App's } \\
\text { Use }\end{array}$ & Graphics & Sound & $\begin{array}{l}\text { User- } \\
\text { Friendly } \\
\text { Design }\end{array}$ \\
\hline 1 & NS & - & $\begin{array}{l}\text { Only in the "target } \\
\text { language" English, } \\
\text { German, French, } \\
\text { and Swedish }\end{array}$ & NS * & + & + & + & + \\
\hline 2 & + & + & Arabic & + & NS & + & + & + \\
\hline 3 & + & + & $\begin{array}{l}\text { English, French, } \\
\text { German, Arabic, } \\
\text { and Persian }\end{array}$ & NS & NS & + & + & + \\
\hline 4 & + & + & Arabic & + & - & + & + & + \\
\hline 5 & + & + & Arabic & - & + & + & + & + \\
\hline 6 & + & + & Arabic & + & NS & + & + & + \\
\hline 7 & + & NS & English and Arabic & NS & NS & + & + & + \\
\hline 8 & NS & NS & German & - & NS & + & + & + \\
\hline 9 & + & - & Arabic and Turkish & - & + & + & + & + \\
\hline 10 & NS & + & $\begin{array}{c}\text { Swedish and } \\
\text { Arabic }\end{array}$ & + & + & + & + & + \\
\hline 11 & + & + & Arabic and English & - & + & + & - & + \\
\hline 12 & - & + & 52 languages & - & + & + & + & + \\
\hline 13 & + & NS & Italian & - & NS & + & + & + \\
\hline 14 & + & NS & $\begin{array}{c}\text { Available in } 9 \\
\text { languages }\end{array}$ & - & NS & + & + & + \\
\hline
\end{tabular}

* Technical and Design Characteristics: + = positive, -=negative, NS = not specified.

To answer the first question of our literature review, it was found that many apps focused on early primary education (5/14). In contrast, the rest focused on higher/adults', primary and secondary education accordingly. The majority of the app content was about language learning (9/14). Analytically, six apps aimed at the host country's language learning and two at native language learning. The rest of the apps' content focused on Literacy acquisition, reading, mathematics, engineering, and vocational training skill.

As far as the second question of this review is concerned, most of the apps (10/14) were free to download and needed no Internet connection for their use (8/14). The language of the apps was: the refugees' native language (4/14), the spoken language of refugees' host country (3/14), and refugees' native language with one more language (i.e., host country's language or English) (4/14). Lastly, three multilingual apps (in 3 or more languages) were found. The majority of the apps included visual and audio representations suitable for the age of their target group and a user-friendly interface. However, only a few apps mentioned scaffolding in their use (technology-based scaffolding) as an included characteristic. A total of 5 of the 14 apps provided instructions in refugees' native language $[78,80,81]$ or both in English and in refugees' native language [63]. Alternatively, in an app with no scaffolding, the same structure navigating the app was adopted as a compensatory way [64].

Refugees' cultural backgrounds seemed to be considered in a small number of apps. The Minclusion app [64] adopted a right to the left layout for app navigation to become familiar to Arabic-speaking refugees. Moreover, the users could share cooking tips and recipes in their native and host country's languages. The Qysas app included traditional tales and stories from refugees' native countries. In the "Feed the monster" app, the game's storyline was similar to refugee children's experiences. Monsters had been forcibly displaced, grew, and evolved prosperously during the game-play [74].

According to users, most of the apps (11/14) included content relevant to refugees' needs. Many refugees stated in their feedback that they found the app content helpful for their everyday lives [63,74,78,81]. However, most of the apps did not clearly state a learning theory. Scaffolding through the learning content was mainly integrated into the 
design of the apps (10/14) since users dealt with leveled difficulty content. In some cases, for engagement purposes, feedback [8,74] or correction feedback [78] was additionally given through audio input.

Moreover, face-to-face support and guidelines were available in two cases (Worldreader app and Project Hope [80,81]), implying a blended learning model. Explanation of scientific terms was found in two apps. Namely, answers were via videos in refugees' native language (2/14 apps). In three apps, educational objectives were interwoven with goals for improving the psychosocial wellbeing of users. While in half of the apps $(7 / 14)$, users had the opportunity to track and evaluate their progress through visual representations visually. On the other hand, in more than half of the apps, the learning theory on which they were based was not clearly stated. Only three apps enabled social interaction, in one of which the possibility of collaborative multiplayer gaming was mentioned [71].

\section{Discussion}

As our research showed, there seemed to be a limited number of articles regarding the mobile education of refugees. The majority of the final selected articles were dated since 2018. This finding is aligned with the rapid increase in applications' design in the past three years [49]. Besides the release period, the level of education and the content area of the found apps seemed to agree with the already existing literature data. Previous research has shown that many mobile learning apps focused mainly on primary and higher -than secondary- education $[50,56,83]$.

Moreover, the mobile apps' content findings agreed with the current literature results. Since the last decade, researchers have recognized that the language barrier was a vital problem for refugees' integration and education. As a result, the majority of the mobile apps for refugees have been focused mainly on teaching their host country's language [20,84]. Less than half of the apps were focused on educational fields other than language acquisition, e.g., literacy skills acquisition, mathematics, engineering, and vocational training skills. According to Taftaf and Williams [8], the breadth of content in mobile learning apps used by refugees changed according to the duration of stay and the place of settlement in the host country. Language learning apps were more used by recently arrived refugees or refugees who live in refugee camps. Refugees, who have lived for a more extended period in their host country and were settled in urban areas, focused mainly on educational-themed apps.

Regarding the technical and design apps characteristics, the need for free-of-charge and non-Internet dependable apps, with age-appropriate multimedia use and scaffolding regarding the learning content $[65,85-87]$, has also been covered in recent mobile apps for refugees $[63,74,78]$. Moreover, the lack of relevance to refugees' lives learning content, mentioned in previous literature as a disadvantage in mobile learning [45], seemed to be seriously considered among the recent apps for refugees. Relevant to refugee population content was considered a criterion of the app's effectiveness [63]. Thus, it was included in the majority of the recent mobile app design. Moreover, previous literature mentioned the increased emotional needs of refugee students [88-90]. In the current systematic literature review, the educational aims of three out of 14 apps were interwoven with features regarding the emotional needs and the psychological wellbeing of refugees $[8,74,80]$.

Besides the content, the literature mentioned that the refugee population's needs and characteristics should also be considered in the apps' design $[19,28,56]$. Findings revealed that some of the found apps included cultural features (such as an appropriate layout from right to left for Arabic-speaking refugees, tales from their tradition, cooking recipes from their home country, etc.). This fact sheds a new perspective on designing mobile learning apps that fulfill a targeted social group. However, further research on the influence factor and the effectiveness of these characteristics is needed.

\section{Limitations of the Study}

Factors that may threaten the validity of this systematic review were found in the process of SLR and the sources' selection. In other reviews, to ensure that the data generated 
are reliable, the analysis was undertaken by two or more researchers who work independently [91]. In the present study, three professionals with diverse backgrounds handled the data screening and inclusion/exclusion [92]. The authors also adopted Kitchenham's [92] recommendations, including grey literature, conference proceedings, and communicating with experts to retrieve a comprehensive list of the studies performed on the topic. Furthermore, the included studies' reference lists and earlier systematic reviews were searched for added relevant articles. Including only published articles might exclude some suitable apps, for which scholarly literature was pending during the SLR's research. Additionally, as non-English studies were excluded in the current review, it might be a source of potential publication bias [93]

\section{Conclusions}

The authors tried to answer two questions about mobile learning for refugees in the current article: (a) what are the recently existing mobile learning apps for refugees? Moreover, (b) what are the characteristics of the recent mobile learning apps for refugees? A systematic literature review was conducted regarding existing mobile apps for refugees from 2015 to 2020. The found features of existing apps were matched with refugee needs, towards an attempt to add to the research about the characteristics that an effective mobile app for refugees should have. Findings showed that apps' content and design were, in some cases, closely associated with refugee characteristics and needs (e.g., living conditions, learning and emotional needs, and socio-cultural differences). There seemed to be a tendency among the apps to be easily accessible regarding the living conditions of refugees (e.g., availability and no need for Internet connectivity) and to contain relevant and valuable content to refugees' everyday lives.

Moreover, this literature review revealed that emotional refugee needs and sociocultural identity were considered in the app's design and game plot on a small scale. For instance, the interweave of psychological with educational features or the inclusion of tales and cooking recipes from refugees' tradition accordingly. However, since the mobile apps, which include refugees' cultural features or combine the educational with psychological features, were limited, further research is needed towards these characteristics and their educational impact. Finally, further research should be conducted focusing on the characteristics of the mobile learning apps for refugees for each targeted level of education.

The current systematic literature review aimed to contribute to a better understanding of the fundamental principles behind the design of mobile learning apps for the heterogeneous group of refugees and the needed characteristics that a mobile learning app for refugees should have. The current research results are essential for educators, game developers, NGOs, and policymakers specializing in mobile learning or distance education. 
Author Contributions: All authors contributed to data collection and/or analysis of project results. All authors have read and agreed to the published version of the manuscript.

Funding: This research received no external funding.

Data Availability Statement: The data presented in this study are available on request from the corresponding author.

Conflicts of Interest: The authors declare no conflict of interest.

\section{Appendix A}

Table A1. The number of research data found in the literature review search during 2018-2020.

\begin{tabular}{|c|c|c|c|c|c|c|c|c|c|c|}
\hline \# & Search Strings & BASE & ERIC & JSTOR & $\begin{array}{l}\text { Learning } \\
\text { Tech } \\
\text { Lib }\end{array}$ & SAGE & SCOPUS & $\begin{array}{c}\text { Taylor } \\
\text { and } \\
\text { Francis }\end{array}$ & $\begin{array}{l}\text { Google } \\
\text { Scholar }\end{array}$ & \\
\hline 1 & $\begin{array}{c}\text { "refugee *" AND (Education } \\
\text { OR instructional OR teaching } \\
\text { OR learning OR training) } \\
\text { AND (app OR game OR } \\
\text { edutainment OR } \\
\text { "smartphone app" OR } \\
\text { "tablet app") }\end{array}$ & 19 & 9 & 13 & 5 & 18 & 5 & 265 & 100 & \\
\hline 2 & $\begin{array}{c}\text { refugee * AND (app OR } \\
\text { game OR edutainment OR } \\
\text { "smartphone app" OR “tablet } \\
\text { app") AND ("mobile } \\
\text { learning" OR “online } \\
\text { learning" OR “electronic } \\
\text { learning" OR } \\
\text { "distant learning" OR } \\
\text { "ubiquitous learning") }\end{array}$ & 23 & 9 & 1 & 20 & 17 & 1 & 19 & 100 & \\
\hline \multirow[t]{2}{*}{3} & refugee AND (app OR game) & 86 & 6 & 22 & 32 & 38 & 70 & 385 & 100 & \\
\hline & Total: & 128 & 24 & 36 & 57 & 73 & 76 & 669 & 300 & 1363 \\
\hline
\end{tabular}




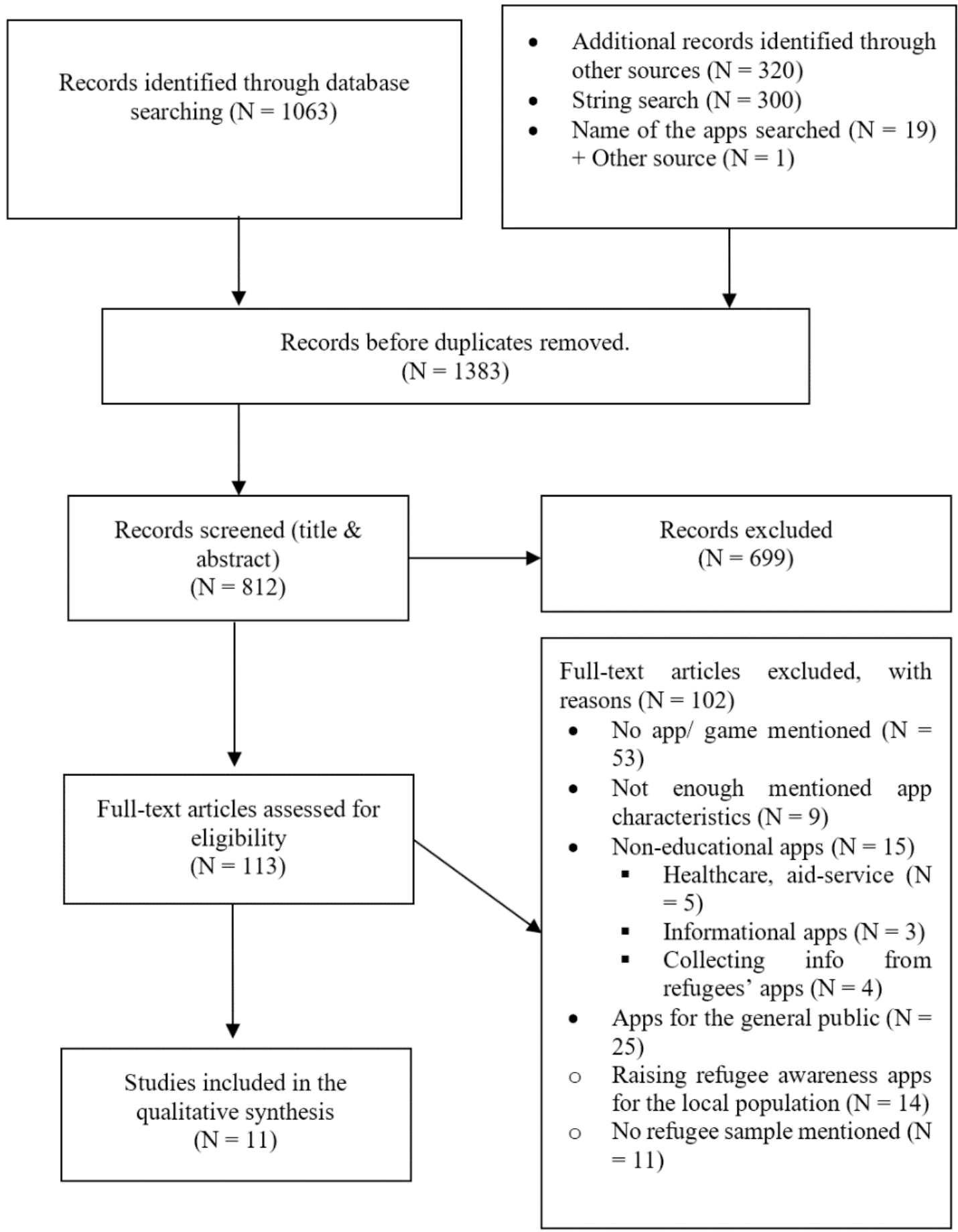

Figure A1. Flow diagram according to PRISMA 2018-2020.

\section{References}

1. AbuJarour, S.A.; Wiesche, M.; Díaz Andrade, A.; Fedorowicz, J.; Krasnova, H.; Olbrich, S.; Tan, C.-W.; Urquhart, C.; Venkatesh, V. ICT-enabled Refugee Integration: A Research Agenda. Commun. Assoc. Inf. Syst. 2019, 44, 874-891. [CrossRef]

2. Fisher, K.E.; Yafi, E. Syrian Youth in Za'atari Refugee Camp as ICT Wayfarers: An Exploratory Study Using LEGO and Storytelling. In Proceedings of the 1st ACM SIGCAS Conference on Computing and Sustainable Societies, San Jose, CA, USA, 20-22 June 2018; pp. 1-12.

3. Cardarelli, R. Solving the education crisis of displaced children: A most important goal for education diplomacy. Child. Educ. 2018, 94, 61-66. [CrossRef]

4. UNHCR. Figures at a Glance. 2021. Available online: https://www.unhcr.org/figures-at-a-glance.html (accessed on 10 November 2021). 
5. Dahya, N.; Dryden-Peterson, S. Tracing pathways to higher education for refugees: The role of virtual support networks and mobile phones for women in refugee camps. Comp. Educ. 2016, 53, 284-301. [CrossRef]

6. UNHCR. Missing out: Refugee Education in Crisis (Publication). 2016. Available online: http://uis.unesco.org/sites/default/ files/documents/missingout-refugee-education-in-crisis_unhcr_2016-en.pdf (accessed on 10 November 2021).

7. UNICEF. Education under Fire: How Conflict in the Middle East Is Depriving Children of Their Schooling. UNICEF, New York, NY. 2015. Available online: http:/ / www.unicef.org/mena/media_10557.html (accessed on 9 November 2021).

8. Taftaf, R.; Williams, C. Supporting Refugee Distance Education: A Review of the Literature. Am. J. Distance Educ. 2019, 34, 5-18. [CrossRef]

9. UNESCO. Global Education Monitoring Report 'Education for People and Planet: Creating Sustainable Futures for All (Report). 2016. Available online: http:/ / unesdoc.unesco.org/images/0024/002457/245752e.pdf (accessed on 21 February 2021).

10. Ally, M.; Balaji, V.; Abdelbaki, A.; Cheng, R. Use of Tablet Computers to Improve Access to Education in a Remote Location. J. Learn. Dev. 2017, 4, 221-228.

11. UNESCO. Protecting the Right to Education for Refugees (Publication). 2017. Available online: http://unesdoc.unesco.org/ images / 0025/002510/251076E.pdf (accessed on 16 November 2021).

12. Organization for Economic Co-operation and Development (OECD). Immigrant Students at School: Easing the Journey towards Integration; OECD Reviews of Migrant Education; OECD Publishing: Paris, France, 2015.

13. Schneeweis, N. Educational institutions and the integration of migrants. J. Popul. Econ. 2011, 24, 1281-1308. [CrossRef]

14. UNHCR. Connecting Refugees: How Internet and Mobile Connectivity Can Improve Refugee Well-Being and Transform Humanitarian Action (Publication). 2016. Available online: http://www.unhcr.org/5770d43c4 (accessed on 10 November 2021)

15. Drolia, M.; Sifaki, E.; Papadakis, S.; Kalogiannakis, M. An Overview of Mobile Learning for Refugee Students: Juxtaposing Refugee Needs with Mobile Applications' Characteristics. Challenges 2020, 11, 31. [CrossRef]

16. UNHCR. Stepping up: Refugee Education in Crisis. 2019. Available online: https://www.unhcr.org/steppingup/wp-content/ uploads/sites/76/2019/09/Education-Report-2019-Final-web-9.pdf (accessed on 10 November 2021).

17. Karim, A.; Hussain, F. 'When Will You Start Teaching the REAL Curriculum?'. In Proceedings of the International Conference on Social Implications of Computers in Developing Countries, Dar es Salaam, Tanzania, 1-3 May 2019; pp. 675-686.

18. Halkic, B.; Arnold, P. Refugees and online education: Student perspectives on need and support in the context of (online) higher education. Learn. Media Technol. 2019, 44, 345-364. [CrossRef]

19. Mason, B.; Buchmann, D. ICT4Refugees-A Report on the Emerging Landscape of Digital Responses to the Refugee Crisis; Federal Mi. Bonn: Deutsche Gesellschaft für InternationaleZusammenarbeit (GIZ); GmbH: Bonn, Germany, 2016. Available online: https://regasus.de/online/datastore?epk=74D5roYc\&file=image_8_en (accessed on 20 November 2021).

20. Ahmad, K.S.; Armarego, J.; Sudweeks, F. Literature review on the feasibility of mobile-assisted language learning (MALL) in developing vocabulary skills among non-English speaking migrant and refugee women. In Proceedings of the 2013 International Conference on Research and Innovation in Information Systems (ICRIIS), Kuala Lumpur, Malaysia, 27-28 November 2013; pp. 336-341.

21. Bradley, L.; Bartram, L.; Al-Sabbagh, K.W.; Algers, A. Designing mobile language learning with Arabic speaking migrants. Interact. Learn. Environ. 2020, 28, 1-13. [CrossRef]

22. Gough, H.A.; Gough, K.V. Disrupted becomings: The role of smartphones in Syrian refugees' physical and existential journeys. Geoforum 2019, 105, 89-98. [CrossRef]

23. Von Baeyer, S.L. "Thinking Outside the Camp": Education Solutions for Syrian Refugees in Jordan. Ethnogr. Prax. Ind. Conf. Proc. 2017, 2017, 444-457. [CrossRef]

24. Kaufmann, K. Navigating a new life: Syrian refugees and their smartphones in Vienna. Inf. Commun. Soc. 2018, 21, 882-898 [CrossRef]

25. Gillespie, M.; Osseiran, S.; Cheesman, M. Syrian Refugees and the Digital Passage to Europe: Smartphone Infrastructures and Affordances. Soc. Media Soc. 2018, 4. [CrossRef]

26. UNESCO. Working Group on Education: Digital Skills for Life and Work (Publication). 2017. Available online: http://unesdoc. unesco.org/images/0025/002590/259013e.pdf (accessed on 15 November 2021).

27. European Commission. Communication from the Commission to the European Parliament, the Council, the European Economic and Social Committee and the Committee of the Regions: Lives in Dignity: From Aid-Dependence to Self-Reliance (COM (2016), 234). Available online: https:/ / ec.europa.eu/echo/files/policies/refugeesdp/Communication_Forced_Displacement_ Development_2016.pdf (accessed on 18 August 2021).

28. Weibert, A.; Krüger, M.; Aal, K.; Salehee, S.S.; Khatib, R.; Randall, D.; Wulf, V. Finding Language Classes: Designing a Digital Language Wizard with Refugees and Migrants. Proc. ACM Hum. Comput. Interact. 2019, 3, 1-23. [CrossRef]

29. Elsafi, A. Formal and Informal Learning Using Mobile Technology. In Mobile and Ubiquitous Learning, Perspectives on Rethinking and Reforming Education; Yu, S., Ally, M., Tsinakos, A., Eds.; Springer Nature: Singapore, 2017; pp. 177-189.

30. Pegrum, M.; Oakley, G.; Faulkner, R. Schools going mobile: A study of the adoption of mobile handheld technologies in Western Australian independent schools. Australas. J. Educ. Technol. 2013, 29, 66-81. [CrossRef]

31. UNESCO. Policy Guidelines for Mobile Learning (Publication). 2013. Available online: http://unesdoc.unesco.org/images/0021 /002196/219641e.pdf (accessed on 16 November 2021). 
32. Keskin, N.O.; Metcalf, D. The current perspectives, theories and practices of mobile learning. Turk. Online J. Educ. Technol. 2011, 10, 202-208.

33. Traxler, J. Distance education and mobile learning: Catching up, taking stock. Distance Educ. 2010, 31, 129-138. [CrossRef]

34. Ng, W.; Nicholas, H.; Loke, S.; Torabi, T. Designing effective pedagogical systems for teaching and learning with mobile and ubiquitous devices. In Multiplatform E-Learning Systems and Technologies: Mobile Devices for Ubiquitous ICT-Based Education; Goh, T.T., Ed.; IGI Global: Hershey, PA, USA, 2009; pp. 42-56.

35. Wang, Y.-S.; Wu, M.-C.; Wang, H.-Y. Investigating the determinants and age and gender differences in the acceptance of mobile learning. Br. J. Educ. Technol. 2009, 40, 92-118. [CrossRef]

36. Lehner, F.; Nosekabel, H. The Role of Mobile Devices in e-Learning-First Experiences with a wireless e-Learning Environment. In Proceedings of the IEEE International Workshop on Wireless and Mobile Technologies in Education, Vaxjo, Sweden, 30 August 2002; Milrad, M., Hoppe, H.U., Kinshuk, Eds.; IEEE Computer Society: Los Angeles, CA, USA, 2002; pp. 103-106.

37. Sung, Y.T.; Chang, K.E.; Liu, T.C. The effects of integrating mobile devices with teaching and learning on students' learning performance: A meta-analysis and research synthesis. Comput. Educ. 2016, 94, 252-275. [CrossRef]

38. Khaddage, F.; Müller, W.; Flintoff, K. Advancing mobile learning in formal and informal settings via mobile app technology: Where to from here, and how? J. Educ. Technol. Soc. 2016, 19, 16-26.

39. Eppard, J.; Nasser, O.; Reddy, P. The next generation of technology: Mobile apps in the English language classroom. Int. J. Emerg. Technol. Learn. 2016, 11, 21-27. [CrossRef]

40. Hwang, G.J.; Tsai, C.C. Research trends in mobile and ubiquitous learning: A review of publications in selected journals from 2001 to 2010. Br. J. Educ. Technol. 2011, 42, E65-E70. [CrossRef]

41. Jeng, Y.-L.; Wu, T.-T.; Huang, Y.-M.; Tan, Q.; Yang, S.J.H. The add-on impact of mobile applications in learning strategies: A review study. Educ. Technol. Soc. 2010, 13, 3-11.

42. Hulse, T.; Daigle, M.; Manzo, D.; Braith, L.; Harrison, A.; Ottmar, E. From here to there! Elementary: A game-based approach to developing number sense and early algebraic understanding. Educ. Technol. Res. Dev. 2019, 67, 423-441. [CrossRef]

43. Kucirkova, N. Personalised Learning with Digital Technologies at Home and School: Where is Children's Agency? In Mobile Technologies in Children's Language and Literacy: Innovative Pedagogy in Preschool and Primary Education; Emerald Publishing Limited: Bingley, UK, 2018; pp. 133-153.

44. Rivera, S.; Banavar, M.K.; Barry, D. Mobile apps for Incorporating Science and Engineering Practices in K-12 STEM Labs. In Proceedings of the 2018 IEEE Frontiers in Education Conference (FIE), San Jose, CA, USA, 3-6 October 2018; pp. 1-5.

45. Heflin, H.; Shewmaker, J.; Nguyen, J. Impact of mobile technology on student attitudes, engagement, and learning. Comput. Educ. 2017, 107, 91-99. [CrossRef]

46. Hwang, G.J.; Wu, P.H. Applications, impacts and trends of mobile technology-enhanced learning: A review of 2008-2012 publications in selected SSCI journals. Int. J. Mob. Learn. Organ. 2014, 8, 83-95. [CrossRef]

47. Hamm, S.; Saltsman, G.; Jones, B.; Baldridge, S.; Perkins, S. A mobile pedagogy approach for transforming learners and faculty. In Handbook of Mobile Learning; Berge, Z., Muilenburg, L., Eds.; Routledge: New York, NY, USA, 2013.

48. Wu, W.H.; Wu, Y.C.J.; Chen, C.Y.; Kao, H.Y.; Lin, C.H.; Huang, S.H. Review of trends from mobile learning studies: A meta-analysis Comput. Educ. 2012, 59, 817-827. [CrossRef]

49. Statista. Worldwide Mobile Education App Downloads from 1st Quarter 2017 to 1st Quarter 2020, by Platform. 2021. Available online: https:/ / www.statista.com/statistics/1128262/mobile-education-app-downloads-worldwide-platforms-millions / (accessed on 23 November 2021).

50. Zydney, J.M.; Warner, Z. Mobile apps for science learning: Review of research. Comput. Educ. 2016, 94, 1-17. [CrossRef]

51. Ting, Y.L. The pitfalls of mobile devices in learning: A different view and implications for pedagogical design. J. Educ. Comput. Res. 2012, 46, 119-134. [CrossRef]

52. Dunleavy, M.; Dede, C.; Mitchell, R. Affordances and limitations of immersive participatory augmented reality simulations for teaching and learning. J. Sci. Educ. Technol. 2009, 18, 7-22. [CrossRef]

53. Rosenbaum, E.; Klopfer, E.; Perry, J. On location learning: Authentic applied science with networked augmented realities. J. Sci. Educ. Technol. 2007, 16, 31-45. [CrossRef]

54. Lamrani, R.; Abdelwahed, E.H. Game-based learning and gamification to improve skills in early years education. Comput. Sci. Inf. Syst. 2020, 17, 339-356. [CrossRef]

55. Colucci, E.; Smidt, H.; Devaux, A.; Vrasidas, C.; Safarjalani, M.; Castaño Muñoz, J. Free digital learning opportunities for migrants and refugees. In An Analysis of Current Initiatives and Recommendations for Their Further Use; JRC Science for Policy Report; Publications Office of the European Union: Luxemburg, 2017.

56. Kukulska-Hulme, A. Mobile Language Learning Innovation Inspired by Migrants. J. Learn. Dev. 2019, 6, 116-119.

57. Adil, M.N.; Sundararaman, V.; Bend, M. Leveraging Educational Technology. In Expectations \& Aspirations: A New Framework of Education in the Middle East and North Africa; Kogali, S.E.T., Kraft, C., Eds.; The World Bank: Washington, DC, USA, 2019.

58. Smyser, H. Chapter 8: Adaptation of Conventional Technologies with Refugee Language Learners: An Overview of Possibilities. In Language, Teaching, and Pedagogy for Refugee Education; Emerald: Bingley, UK, 2019; pp. 125-139.

59. Zhang, Y. Handbook of Mobile Teaching and Learning; Springer: Berlin, Germany, 2015. 
60. Sabie, D.; Ahmed, S.I. Moving into a technology land: Exploring the challenges for the refugees in Canada in accessing its computerized infrastructures. In Proceedings of the 2nd ACM SIGCAS Conference on Computing and Sustainable Societies, Accra, Ghana, 3-5 July 2019; pp. 218-233.

61. Menashy, F.; Zakharia, Z. Private engagement in refugee education and the promise of digital humanitarianism. Oxf. Rev. Educ. 2020, 46, 313-330. [CrossRef]

62. ANSA. Italy: Gamified App Assists Migrants with Job Search. INFO-MIGRANTS. 2020. Available online: https://www. infomigrants.net/en/post/25556/italy-gamified-app-assists-migrants-with-job-search (accessed on 23 November 2021).

63. De Freitas, C.C.S.; DeBoer, J. A Mobile Educational Lab Kit for Fragile Contexts. In Proceedings of the 2019 IEEE Global Humanitarian Technology Conference (GHTC), Seattle, WA, USA, 17-20 October 2019; pp. 1-7.

64. Al-Sabbagh, K.W.; Bradley, L.; Bartram, L. Mobile language learning applications for Arabic speaking migrants—A usability perspective. Lang. Learn. High. Educ. 2019, 9, 71-95. [CrossRef]

65. CastaňoMuňoz, J.; Colucci, E.; Smidt, H. Free Digital Learning for Inclusion of Migrants and Refugees in Europe: A Qualitative Analysis of Three Types of Learning Purposes. Int. Rev. Res. Open Distrib. Learn. 2018, 19, 1-21.

66. Haddaway, N.R.; Collins, A.M.; Coughlin, D.; Kirk, S. The role of Google Scholar in evidence reviews and its applicability to grey literature searching. PLoS ONE 2015, 10, e0138237. [CrossRef]

67. Meyer, M.; Zosh, J.M.; McLaren, C.; Robb, M.; McCafferty, H.; Golinkoff, R.M.; Hirsh-Pasek, K.; Radesky, J. How educational are "educational" apps for young children? App store content analysis using the Four Pillars of Learning framework. J. Child. Media 2021, 15, 526-548. [CrossRef]

68. Hirsh-Pasek, K.; Zosh, J.M.; Golinkoff, R.M.; Gray, J.H.; Robb, M.B.; Kaufman, J. Putting education in "educational" apps: Lessons from the science of learning. Psychol. Sci. Public Interest 2015, 16, 3-34. [CrossRef]

69. Tahir, R.; Wang, A.I. How to Evaluate Educational Games with Refugee Children: Methodological Aspects and Lessons Learned from EduApp4syria. In Proceedings of the 13th International Conference on Game Based Learning, Odense, Denmark, 3-4 October 2019; pp. 722-730.

70. Gabriel, S. The potential of serious digital games for human rights education. In Proceedings of Play2Learn 2018; Tyner, K., Costa, C., Eds.; CICANT: Lisbon, Portugal, 2018; pp. 52-66.

71. Jantke, K.P.; Arnold, O.; Bosecker, T. Exploratory Game Play to Support Language Learning: Dinner Talk. In Proceedings of the 8th International Conference on Computer Supported Education (CSEDU 2016), Rome, Italy, 21-23 April 2016; Volume 2, pp. 161-166.

72. Schuldt, J.; Sachse, S.; Buckens, L. Dinner Talk: A Language Learning Game Designed for the Interactive Table. In Online Engineering $\mathcal{E}$ Internet of Things; Lecture Notes in Networks and Systems 22; Auer, M., Zutin, D., Eds.; Springer: Cham, Switzerland, 2018.

73. Stubbé, H.; Badri, A.; Telford, R.; van der Hulst, A.; van Joolingen, W. E-Learning Sudan, Formal Learning for Out-of-School Children. Electron. J. e-Learn. 2016, 14, 136-149.

74. Koval-Saifi, N.; Plass, J. Feed the Monster: Impact and Technical Evaluation; World Vision and Foundation for Information Technology Education and Development: Washington, DC, USA, 2018.

75. Brown, F.L.; Farag, A.I.; Hussein Abd Alla, F.; Radford, K.; Miller, L.; Neijenhuijs, K.; Stubbé, H.; de Hoop, T.; Abbadi, A.A.; Turner, J.S.; et al. Can't Wait to Learn: A quasi-experimental mixed-methods evaluation of a digital game-based learning programme for out-of-school children in Sudan. J. Dev. Eff. 2020. [CrossRef]

76. Benton, M.; Glennie, A. Digital Humanitarianism: How Tech Entrepreneurs Are Supporting Refugee Integration. 2016. Available online: http:/ / www.migrationpolicy.org/research/digital-humanitarianismhow-tech-entrepreneurs-are-supporting-refugeeintegration (accessed on 29 November 2021).

77. Comings, J.P. A case study of innovations that address constraints on the effectiveness of early grade reading achievement. PROSPECTS 2020, 1-16. [CrossRef]

78. Koval-Saifi, N.; Plass, J. Antura and the Letters: Impact and Technical Evaluation; World Vision and Foundation for Information Technology Education and Development: Washington, DC, USA, 2018.

79. Baldi, V.; Ribeiro, A. Conceptualization of a mobile application aimed at refugees in Portugal. In Proceedings of the 201813 th Iberian Conference on Information Systems and Technologies (CISTI), Caceres, Spain, 13-16 June 2018; pp. 1-6.

80. Sirin, S.; Plass, J.L.; Homer, B.D.; Vatanartiran, S.; Tsai, T. Digital game-based education for Syrian refugee children: Project Hope. Vulnerable Child. Youth Stud. 2018, 13, 7-18. [CrossRef]

81. Smith, W.; Crane, A. Worldreader: Leveraging Mobile Phones for Reading to Young Children in India and Jordan. Child. Educ. 2019, 95, 6-15. [CrossRef]

82. Fulantelli, G.; Taibi, D.; Todaro, G.; Pipitone, V.; La Guardia, D.; Arrigo, M. A mobile learning platform to guarantee education continuity for unaccompanied foreign minors and refugees. In Proceedings of EdMedia + Innovate Learning; Bastiaens, J.T., Ed.; Association for the Advancement of Computing in Education (AACE): Amsterdam, The Netherlands, 2019; pp. 1636-1640.

83. Jalbout, M.; Farah, S. Exploring the potential of technology to deliver education and skills to Syrian refugee youth. In Global Business Coalition for Education \& Their World; Brookings: Washington, DC, USA, 2016. 
84. Lindström, N.B.; Hashemi, S.S.; Bartram, L.; Bradley, L. Mobile resources for integration: How availability meets the needs of newly arrived Arabic-speaking migrants in Sweden. In CALL in a Climate of Change: Adapting to Turbulent Global Conditions-Short Papers from EUROCALL 2017; Borthwick, K., Bradley, L., Thouësny, S., Eds.; Research-Publishing.net.: Voillans, France, 2017; pp. 40-45.

85. Papadakis, S.; Kalogiannakis, M.; Zaranis, N. Designing and creating an educational app rubric for preschool teachers. Educ. Inf. Technol. 2017, 22, 3147-3165. [CrossRef]

86. Lewis, K.; Thacker, S. ICT and the Education of Refugees: A Stocktaking of Innovative Approaches in the MENA Region; World Bank Education, Technology \& Innovation: SABER-ICT Technical Paper Series. No. 17; The World Bank: Washington, DC, USA, 2016.

87. Maitland, C.; Xu, Y. A Social Informatics Analysis of Refugee Mobile Phone Use: A Case Study of Za'atari Syrian Refugee Camp. In Proceedings of the TPRC 43: The 43rd Research Conference on Communication, Information and Internet Policy Paper, Arlington, VA, USA, 25-27 September 2015.

88. Cerna, L. Refugee Education: Integration Models and Practices in OECD Countries; OECD Education Working Papers, No. 203; OECD Publishing: Paris, France, 2019.

89. Branson, D.C. Student trauma, the hidden curriculum, and cultural humility: This trio needs a team approach. In Addressing Multicultural Needs in School Guidance and Counseling; Taukeni, S.G., Ed.; IGI Global: Hershey, PA, USA, $2019 ;$ pp. 82-105.

90. Sirin, S.R.; Rogers-Sirin, L. The Educational and Mental Health Needs of Syrian Refugee Children; Migration Policy Institute: Washington, DC, USA, 2015.

91. Thomé, A.M.T.; Scavarda, L.F.; Scavarda, A.J. Conducting Systematic Literature Review in Operations Management. Prod. Plann. Control. 2016, 27, 408-420. [CrossRef]

92. Kitchenham, B. Procedures for Performing Systematic Reviews; Joint Technical Report; Computer Science Department, Keele University (TR/SE0401): Newcastle, UK; National ICT Australia Ltd.: Eversleigh, Australia, 2004.

93. Kitchenham, B.; Charters, S. Guidelines for Performing Systematic Literature Reviews in Software Engineering; Technical Report EBSE-2007-01; School of Computer Science and Mathematics, Keele University: Newcastle, UK, 2007. 